\title{
In vitro AND in silico EVALUATION OF THYMOQUINONE AS POTENTIAL ANTICANCER AGENT IN HUMAN ACUTE MYELOID LEUKEMIA HL-60 CELLS
}

\author{
Neslihan TEKİN KARACAER \\ Department of Biotechnology, Faculty of Science and Letters, Aksaray University, Aksaray, TURKEY \\ neslihan_tekin@hotmail.com ORCID: 0000-0002-0091-6428
}

Cite this article as:

Tekin Karacaer N. 2022. In vitro and in silico evaluation of thymoquinone as potential anticancer agent in human acute myeloid leukemia HL-60 cells. Trakya Univ J Nat Sci, 23(1): 53-63, DOI: 10.23902/trkjnat.999403

Received: 23 September 2021, Accepted: 05 January 2022, Online First: 03 February 2022, Published: 15 April 2022

Edited by:

Enes Taylan

Key words:

$A M L$

Apoptosis

Autophagy

Molecular docking

PI3K/AKT/mTOR

Thymoquinone

\begin{abstract}
This study aims to explore the cytotoxic, apoptotic and autophagic effects of thymoquinone on human acute myeloid leukemia. The cytotoxic effects of thymoquinone were determined with 3-(4, 5-dimethylthiazol-2-yl)-2 and 5-diphenyltetrazolium bromide (MTT) tests. B-cell lymphoma 2 associated X protein (Bax), B-cell lymphoma 2 (Bcl-2), caspase 3, mammalian target of rapamycin (mTOR), phosphatidylinositol-3-kinase (PI3K), and protein kinase $\mathrm{B}$ (AKT) gene expression analyzes were studied with quantitative realtime polymerase chain reaction (qRT-PCR). AutoDock Tools 4.2 software was applied to research the potential binding of thymoquinone in the active sites of Bax, Bcl-2, caspase 3, mTOR, PI3K, and AKT proteins. Thymoquinone caused a cytotoxic effect on HL-60 cells (Human leukemia cell line) with a value of $16.35 \mu \mathrm{M}$. Bcl-2 expression was decreased in all concentrations applied compared to the control. A decrease in caspase 3 expression level was detected in the cells treated with $10 \mu \mathrm{M}, 15 \mu \mathrm{M}$, and $25 \mu \mathrm{M}$ thymoquinone compared to the control. Thymoquinone induced an important decrease in mTOR and PI3K expressions compared to the control at all doses, while AKT decreased at a dose of $15 \mu \mathrm{M}$. The docking outcomes showed that thymoquinone interacts with the active site amino acids of apoptotic and autophagic proteins via hydrophobic interactions and hydrogen bonding. The present findings suggest that thymoquinone can stimulate autophagy by prevention of PI3K/AKT/mTOR pathway in HL-60 cells and may become a new target for the therapy of acute myeloid leukemia.
\end{abstract}

Özet: Bu çalışmada, insan akut miyeloid lösemisinde timokinonun sitotoksik, apoptotik ve otofajik etkilerinin araştırılması amaçlandı. Timokinonun sitotoksik etkileri 3-(4,5dimetiltiyazol2-yl)-2,5-difeniltetrazolyum-bromür (MTT) testi ile belirlendi. B hücre lenfoma 2 ile ilişkili X proteini (Bax), B hücre lenfoma 2 (Bcl-2), kaspaz 3, rapamisinin memeli hedefi (mTOR), fosfatidilinositol-3-kinaz (PI3K) ve protein kinaz B (AKT) gen ekspresyon analizleri kantitatif gerçek zamanlı polimeraz zincir reaksiyonu (qRT-PCR) ile yapıldı. Bax, Bcl-2, kaspaz 3, mTOR, AKT ve PI3K proteinlerinin aktif bölgesindeki timokinonun potansiyel bağlanmasını araştırmak için AutoDock Tools 4.2 yazılımı kullanıldı. Timokinon, HL-60 hücrelerinde (İnsan lösemi hücre hattı) $16.35 \mu \mathrm{M}$ değerinde sitotoksik etkiye neden olmuştur. Uygulanan tüm dozlarda kontrole göre Bcl-2 ekspresyonu azalmıştır. $10 \mu \mathrm{M}, 15 \mu \mathrm{M}$ ve $25 \mu \mathrm{M}$ timokinon ile tedavi edilen hücrelerde kontrole göre kaspaz 3 ekspresyon seviyesinde bir azalma tespit edildi. Timokinon, tüm dozlarda kontrole kıyasla mTOR ve PI3K ifadelerinde önemli bir azalmaya neden olurken, AKT $15 \mu$ M'lik bir dozda azaldı. Yerleştirme sonuçları, timokinonun apoptotik ve otofajik proteinlerin aktif bölge amino asitleri ile hidrofobik etkileşimler ve hidrojen bağ yoluyla etkileşime girdiğini belirtti. Bulgularımız, timokinonun HL-60 hücrelerinde PI3K/AKT/mTOR yolunu önleyerek otofajiyi uyarabildiğini ve akut miyeloid lösemi tedavisi için yeni bir hedef olabileceğini düşündürmektedir.

\section{Introduction}

Acute myeloid leukemia (AML) is the most common type of leukemia in which myeloblast accumulation takes place due to both differentiation failure and excessive proliferation of stem cells (Maha et al. 2008). The incidence of AML increases substantially with age. Most of the aged patients are not suitable to be cured with intense chemotherapy or bone marrow transplantation. Lack of adequate and less damaging treatments leads to a 
very low therapy proportion of only $5-15 \%$ of these patients (Kahl et al. 2019). AML chemotherapy drugs produce side effects such as infection, bleeding, and anemia and can damage healthy cells and tissues (Bashmail et al. 2020). Therefore, a new therapeutic agent with fewer side effects needs to be found to treat AML and scientists are exploring natural materials that can be used for this purpose.

Natural compounds and even raw herbs pose promising alternative drug sources in cancer treatment. They are known to suppress or block carcinogenic processes (Bashmail et al. 2018). Thymoquinone is one of the main bioactive constituents isolated from Nigella sativa L., and it has anti-oxidant, anti-inflammation, antihypertensive and anti-tumor properties (Ahmad et al. 2013, Bashmail et al. 2018). Earlier studies have shown that thymoquinone has antitumor effects on various cancer types such as cervical squamous carcinoma ( $\mathrm{Ng}$ et al. 2011), breast cancer (Woo et al. 2011), pancreatic cancer (Banerjee et al. 2009), skin cancer (Gali-Muhtasib et al. 2004b), osteosarcoma (Peng et al. 2013), colorectal carcinoma (Gali-Muhtasib et al. 2004a), glioblastoma (Gurung et al. 2010) and bladder cancer (Zhang et al. 2018a). On the other hand, it remains unclear whether thymoquinone has anti-cancer activity in AML. Although the effect of thymoquinone has been studied on many cancer types, the molecular mechanisms underlying its effect remain to be elucidated.

In some recent studies, thymoquinone has been reported to exhibit anticancer activities including induction of apoptosis (El-Mahdy et al. 2005) and autophagy (Zhang et al. 2018b) in different cancer cells. Autophagy and apoptosis are important mechanisms that determine the survival or death of cancer cells (Sun et al. 2019). Supporting and regulatory genes are included in apoptotic pathway. As the failure of the apoptotic process can cause drug resistance or tumor development, it is important to investigate new drugs that may affect the process (Artun \& Karagöz 2021). Apoptosis is arranged by Bcl-2 family proteins and caspases. Autophagy is a survival mechanism stimulated in a problematic environment to preserve cell integrity by metabolic stress and/or food starvation. Autophagy is activated in conditions such as cell stress and damage, aging, pathogen infection (Chang et al. 2017) and deprivation of oxygen and growth factors (Meng et al. 2020). Studies show that two different cell deaths can be induced by communal signs that influence the development and treatment of cancer such as B-cell lymphoma 2 (Bcl-2), phosphatidylinositol-3-kinase (PI3K)/protein kinase B (AKT)/mammalian target of rapamycin (mTOR) pathway, and p53 (Ge et al. 2013, Krumar et al. 2015, Liu et al. 2018, Saiki et al. 2011, Zhou et al. 2015). $\mathrm{PI} 3 \mathrm{~K} / \mathrm{AKT} / \mathrm{mTOR}$ pathway shows a central function in cell metabolism, cell proliferation, cell cycle progression, angiogenesis, autophagy and apoptotic cell death. It represents one of the main survival pathways that is unregulated in different cancer types and contributes to cancer pathogenesis and treatment resistance. This pathway, which is structurally active in most malignancies, leads to inhibition of programmed cell death and promotion of cell survival (Liu et al. 2018). Thus, the prevention of PI3K/AKT/mTOR signaling pathway could have enormous potential to induce cell death related with apoptosis and/or autophagy. On the other hand, the detailed mechanisms of diverse antitumor agent therapies, specifically natural remedies, which may contain diverse programmed cell deaths to some extent, are still not understood.

How thymoquinone induces cell death and whether the genes involved in these pathways play a role in thymoquinone induced cell death are not completely known. The present study explored the cytotoxic effect of thymoquinone and its effect on apoptotic and autophagic mechanisms by using the acute myelogenous leukemia cell line HL-60 (Human leukemia cell line). Additionally, molecular docking was also done to define the mechanism of anticancer activity of thymoquinone. The findings propose that thymoquinone prevents the growth of HL-60 cells inducing autophagy through down-regulation of Bcl2 and PI3K/AKT/mTOR pathways.

\section{Materials and Methods}

\section{Cell Culture}

HL-60 cell line which modeled acute myeloid leukemia was used as cancer cells (Al-Otaibi et al. 2019). HL-60 cell line was obtained from İzmir Institute of Technology (İzmir, Turkey). HL-60 cells were grown in the presence of RPMI 1640 medium (Life Technologies), $10 \%$ warmth inactivated fetal bovine serum (Life Technologies), and $1 \%$ penicillin-streptomycin (100 $\mathrm{U} / \mathrm{mL}$ ) (Life Technologies). The cells were cultivated at $37^{\circ} \mathrm{C}$ in a humidified incubator with $5 \% \mathrm{CO}_{2}$ and $95 \%$ air atmosphere. The passage was done every 2 days.

A stock solution of thymoquinone $(10 \mathrm{mM})$ was prepared by dissolving a defined amount of thymoquinone in dimethyl sulfoxide (DMSO) and stored at $4^{\circ} \mathrm{C}$. The last volume of DMSO in the cells was less than $0.1 \%$.

\section{Methyl Thiazolyl Tetrazolium (MTT) Cell Viability} $\underline{\text { Assay }}$

Cell viability was analyzed based on MTT method according to the assay of Mossman (1983). From the cells in the appropriate medium, $7.5 \times 10^{3}$ cells per $100 \mu 1$ per well were distributed into 96-well microplates. After $24 \mathrm{~h}$ of incubation, different concentrations of thymoquinone $(1 \mu \mathrm{M}, 5 \mu \mathrm{M}, 10 \mu \mathrm{M}, 15 \mu \mathrm{M}$, and $20 \mu \mathrm{M})$ were added on the cells, and the total volume was completed to $200 \mu \mathrm{L}$. Thymoquinone treated cells were incubated at $37^{\circ} \mathrm{C}$ in the presence of $5 \% \mathrm{CO}_{2}$ and $95 \%$ humidity for $24 \mathrm{~h}$. After incubation, $20 \mu \mathrm{L}$ of MTT $(5 \mathrm{mg} / \mathrm{mL}$ phosphate buffer saline, $\mathrm{pH}$ 7.2) solution was added to each well, and the platelets were kept in a $\mathrm{CO}_{2}$ oven for $4 \mathrm{~h}$. Then, the medium on the cells was aspirated, and $100 \mu \mathrm{L}$ of DMSO was added to each well and incubated at $37^{\circ} \mathrm{C}$ for 10 
minutes. The colored solution was quantified at a wavelength of $570 \mathrm{~nm}$ via a microplate reader (Bio-Rad model 680 microplate reader). All investigations were done in triplicates for thymoquinone. Cell viability was measured by $($ Test OD/Control OD) $\times 100$. Polynomial regression analysis was performed through Microsoft Excel to determine the half-maximum inhibitory concentration $\left(\mathrm{IC}_{50}\right)$ values of thymoquinone.

\section{RNA Isolation and cDNA Synthesis}

Total RNA for cDNA synthesis was extracted from the cells using the PureLinkTM Mini Kit (Life Technologies, Carlsbad, CA, USA) procedure. Quality and quantity of the whole RNA samples were measured through NanoDrop 2000 Spectrophotometer (Thermo Scientific, USA). The first-strand cDNA was produced through reverse transcriptase using total RNA isolated from the cells using High Capacity cDNA reverse Transcription Kit (Applied Biosystems, Foster City, CA) following the process specified in the user manual. cDNA products were diluted in nuclease-free water at $42^{\circ} \mathrm{C}$ for $1 \mathrm{~h}$ and stored at $-20^{\circ} \mathrm{C}$ before further analysis.

\section{$\underline{P C R}$}

Gene Expression Analysis by Quantitative Real-Time

Quantitative reverse transcriptase-polymerase chain reaction (qRT-PCR) for specification of B-cell lymphoma 2 associated $\mathrm{X}$ protein (Bax), Bcl-2, caspase 3, PI3K, AKT, and mTOR gene expressions were done via a 7500 Fast Real Time PCR (Applied Biosystems). Bax, Bcl-2, caspase 3, PI3K, AKT, and mTOR gene expression quantities were obtained using TaqMan gene expression kits (Applied Biosystems, Foster City, CA) following manufacturer's protocols (Table 1). PCR mix solution was contained in diluted complementary DNA (cDNA) genespecific TaqMan gene expression kit and TaqMan master mix (Applied Biosystems) in a final volume. qRT-PCR data were assessed through an ABI PRISM 7500 Sequence Detection system (Applied Biosystems). Every sample was assayed in triplicate.

Table 1. IDs for tagman gene expression assay.

\begin{tabular}{cc}
\hline \hline Target gene & Assay ID \\
\hline \hline Bax & Hs00180269_m1 FAM-MGB \\
Bcl-2 & Hs00608023_m1 FAM-MGB \\
caspase 3 & Hs00234387_m1 FAM-MGB \\
mTOR & Hs00234522_m1 (FAM-MGB) \\
PI3KCA & Hs00907957_m1 (FAM-MGB) \\
AKT1 & Hs00178289_m1 (FAM-MGB) \\
\hline \hline
\end{tabular}

\section{Molecular Docking Studies}

Docking analysis was applied within Bax (PDB code:1F16), Bcl-2 (PDB code:2W3L), caspase 3 (PDB code:3KJF), PI3K (PDB code: 5JHB), AKT (PDB code: $3 \mathrm{MVH}$ ), and mTOR (PDB code: $3 \mathrm{JBZ}$ ) active sites, which were obtained from the protein data bank server (http://www.rcsb.org). The two-dimensional (2D) structure of thymoquinone was downloaded from
Pubchem compound database (http://www.ncbi.nlm.nih.gov/search). The three dimensional (3D) structure for thimoquinone was generated using ACD/ChemSketch (Fig. 1). The structures of thymoquinone were submitted to the protein preparation module of AutoDock Tools 4.2 molecular modeling software (Morris et al. 2009). In molecular docking simulations, Glide/XP docking protocols were applied to predict the topology of thymoquinone in the active site of the target structure. Thymoquinone was docked to the active site of targets (Bax, Bcl-2, caspase 3, PI3K, AKT, and mTOR) using AutoDock Tools 4.2 molecular modeling software (Schrödinger Release 20162: Schrödinger, LLC, New York, NY, USA). The binding energy of docked molecules was computed via X-Score. The amino acid residues hydrophobic interactions and making hydrogen bonding were calculated making hydrogen bonding via Getneares, which is a device obtainable with DOCKv5.1.1.

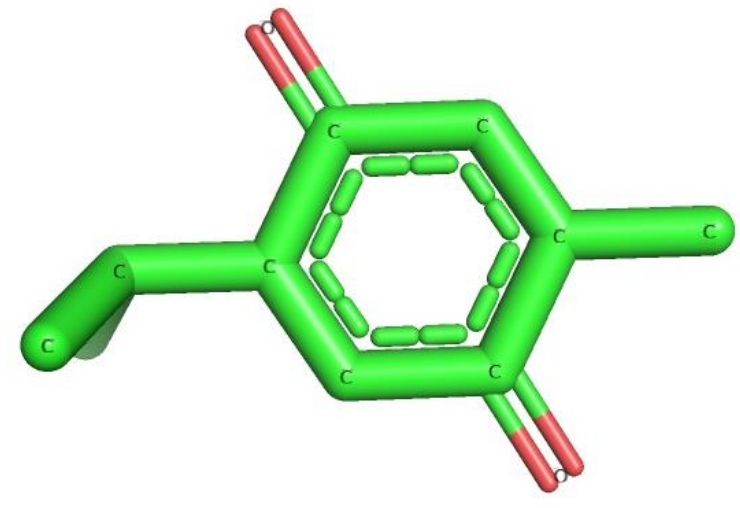

Fig. 1. Structure of thymoquinone.

\section{Statistical Analysis}

$\mathrm{IC}_{50}$ value was determined using Microsoft Excel program. All statistical analyses were done by Statistical Package for Social Sciences (SPSS) version 18.0 statistic software package (SPSS Inc, Chicago, Illinois). Statistical significances were compared by one-way analysis of variance (ANOVA) with Tukey's post-hoc test. Differences among the treated doses with $p<0.05$ was regarded as statistically significant.

\section{Results \\ Cell Viability}

In order to evaluate the cytotoxicity ability, MTT analysis of thymoquinone at diverse concentrations against HL-60 cells were conducted for the incubation duration of $24 \mathrm{~h}$, and the outcomes are presented in Fig. 2. It was determined that the cell viability decreased by $1.3,2$, and 2.7 times in the groups treated with $10 \mu \mathrm{M}, 15$ $\mu \mathrm{M}$ and $20 \mu \mathrm{M}$ thymoquinone, respectively, compared to the control group $(\mathrm{p}=0.006, \mathrm{p}<0.001, \mathrm{p}<0.001)$. $\mathrm{IC}_{50}$ concentrations for the thymoquinone were calculated from the dose response curves. Thymoquinone was exposed to cytotoxicity against HL-60 cell line with an $\mathrm{IC}_{50}$ value of $16.35 \mu \mathrm{M}$. 


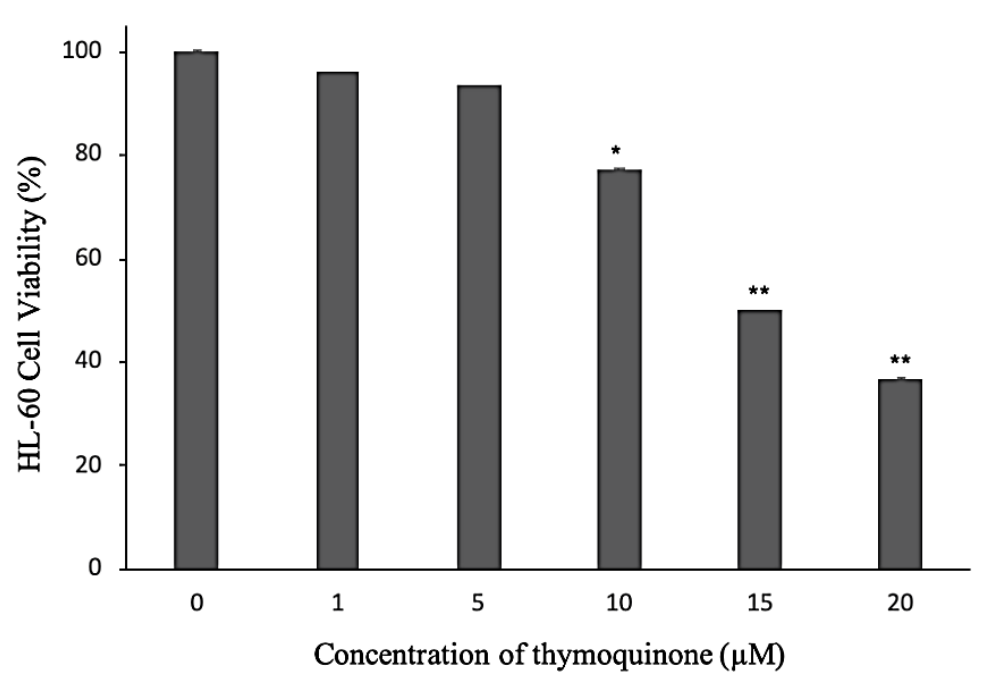

Fig. 2. The effect of thymoquinone on HL-60 cell viability after $24 \mathrm{~h}$ exposure. The results are expressed as means $\pm \mathrm{SD}$ from three independent experiments. $*$ indicates $\mathrm{p}<0.01$ and $* *$ indicates $\mathrm{p}<0.001$ versus control.

Bax

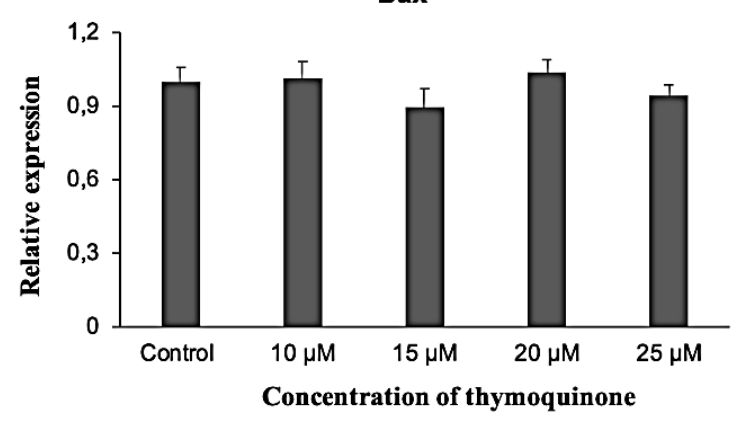

Caspase 3

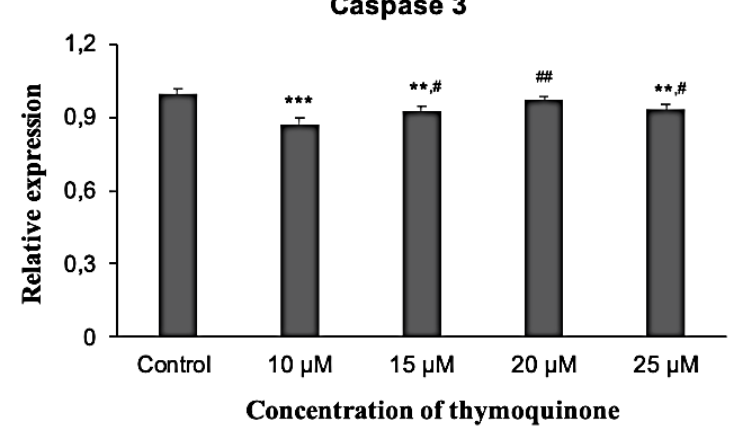

$\mathrm{Bcl}-2$

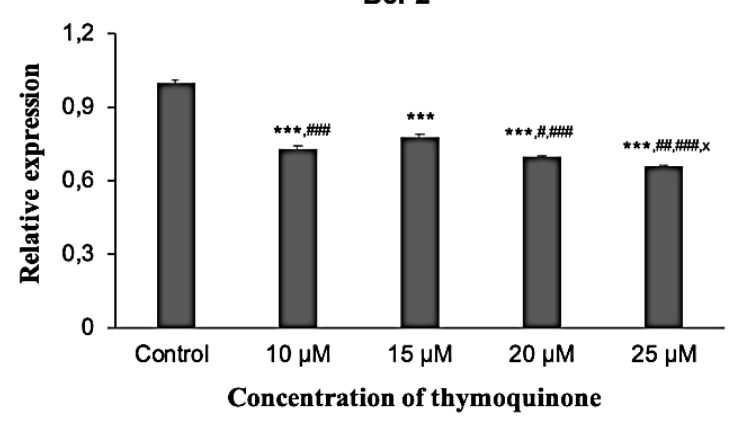

$\mathrm{Bax} / \mathrm{Bcl}-2$ ratio

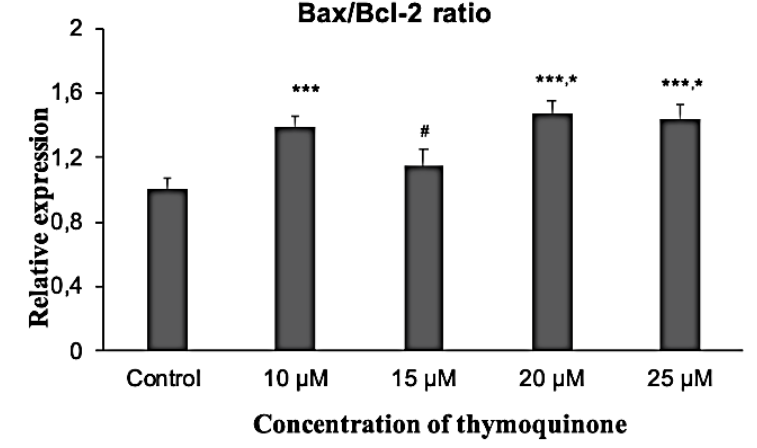

Fig. 3. The effects of thymoquinone on expression levels of Bax, Bcl-2, caspase 3, and the ratio of Bax/Bcl-2 genes in HL-60 cells. The values of each group were given as mean \pm standard deviation (SD). $* * * p<0.001$ significant difference compared to the control, **p $<0.01$ significant difference compared to the control, \# $\mathrm{p}<0.05$ significant difference compared to $10 \mu \mathrm{M}$ treatment group, \#\#p $<0.001$ significant difference compared to $10 \mu \mathrm{M}$ treatment group, \#\#\# $\mathrm{p}<0.001$ significant difference compared to $15 \mu \mathrm{M}$ treatment group, ${ }^{*} \mathrm{p}<0.01$ significant difference compared to $15 \mu \mathrm{M}$ treatment group, ${ }^{\mathrm{x}} \mathrm{p}<0.001$ significant difference compared to $20 \mu \mathrm{M}$ treatment group.

\section{The Effect of Thymoquinone on Gene Expression} Levels of Bax, Bcl-2, caspase 3, and Ratio of Bax/Bcl-2 Genes in HL-60 Cells

Bax and Bcl-2 genes are members of Bcl-2 family and exhibit a significant function in apoptotic cell death (Chen et al. 2017). Therefore, the expression of these genes were evaluated. The results are presented in Fig. 3. Bax and $\mathrm{Bcl}-2$ gene expression levels were determined in HL-60 cells treated with control and four different doses of thymoquinone ( $10 \mu \mathrm{M}, 15 \mu \mathrm{M}, 20 \mu \mathrm{M}$, and $25 \mu \mathrm{M})$. There was no statistically significant difference in Bax gene expression levels between the groups $(\mathrm{p}=0.999, \mathrm{p}=0.256$, $\mathrm{p}=0.944, \mathrm{p}=0.764$ ). No significant difference was also 
found in Bax values between the groups treated with thymoquinone. Bcl-2 gene expression levels were found to be lower in the groups treated with thymoquinone compared to the control group $(\mathrm{p}<0.001, \mathrm{p}<0.001, \mathrm{p}$ $<0.001, \mathrm{p}<0.001)$. Bcl-2 gene expression level in the cells which were treated with $25 \mu \mathrm{M}$ thymoquinone was determined to be lower than the other experiment groups ( $\mathrm{p}<0.001, \mathrm{p}<0.001, \mathrm{p}<0.001)$. However, it was determined that Bcl-2 gene expression level was lower in the group treated with $20 \mu \mathrm{M}$ thymoquinone compared to the groups treated with $10 \mu \mathrm{M}$ and $15 \mu \mathrm{M}$ thymoquinone $(\mathrm{p}=0.021$ for $10 \mu \mathrm{M}, \mathrm{p}<0.001$ for $15 \mu \mathrm{M}$ ). Bcl-2 family shows proapoptotic or antiapoptotic effects by affecting caspase 3 activity (Chen et al. 2017). Therefore, the gene expression level of caspase 3 was also analyzed in the present study. The results are presented in Fig. 3. Caspase 3 gene expression levels were determined in HL-60 cells treated with the control and four different doses of thymoquinone (10 $\mu \mathrm{M}, 15 \mu \mathrm{M}, 20 \mu \mathrm{M}$, and $25 \mu \mathrm{M})$. When caspase 3 gene expression level was evaluated, there was no statistically significant difference among the control group and the cells treated with $20 \mu \mathrm{m}$ (Pp=0.430). The treatments with $10 \mu \mathrm{m}, 15 \mu \mathrm{m}$, and 25 $\mu \mathrm{m}$ thymoquinone significantly reduced caspase 3 levels compared to the control ( $\mathrm{p}<0.001, \mathrm{p}=0.004, \mathrm{p}=<0.006)$. A reduction was stated on caspase 3 gene expression level at $10 \mu \mathrm{M}$ thymoquinone treatment compared to other thymoquinone treated groups $(\mathrm{p}=0.032, \mathrm{p}<0.001$, $\mathrm{p}=0.020)$. The findings also showed a significant increase in $\mathrm{Bax} / \mathrm{Bcl}-2$ ratio in cure by thymoquinone $(10 \mu \mathrm{M}, 20$ $\mu \mathrm{M}$, and $25 \mu \mathrm{M})(\mathrm{p}=0.001, \mathrm{p}<0.001 \mathrm{p}<0.001)$. The ratio of Bax/Bcl-2 also increased considerably at $10 \mu \mathrm{M}$ $(\mathrm{p}=0.029), 20 \mu \mathrm{M}(\mathrm{p}=0.004)$ and $25 \mu \mathrm{M}(\mathrm{p}=0.008)$ concentrations compared to the group treated with $15 \mu \mathrm{M}$ thymoquinone (Fig. 3).

The Effect of Thymoquinone on Gene Expression Levels of $\mathrm{mTOR}, \mathrm{PI} 3 \mathrm{~K}$, and AKT Genes in HL-60 Cells

$\mathrm{PI} 3 \mathrm{~K} / \mathrm{AKT} / \mathrm{mTOR}$ pathway is one of the main signaling pathways activated in cancer cells (Liu et al. 2018). Therefore, the influence of thymoquinone on $\mathrm{PI} 3 \mathrm{~K} / \mathrm{AKT} / \mathrm{mTOR}$ pathway was explored. The results of different treatment doses of thymoquinone on gene expression levels of mTOR, PI3K, and AKT genes in HL60 cells are shown in Fig. 4. It was determined that the mTOR and PI3K gene expression levels were diminished in the cell groups treated with thymoquinone compared to the control group $(\mathrm{p}<0.001, \mathrm{p}<0.001, \mathrm{p}<0.001, \mathrm{p}$ $<0.001)$. There was a decrease in PI3K gene expression in thymoquinone groups treated with $15 \mu \mathrm{M}, 20 \mu \mathrm{M}$, and 25 $\mu \mathrm{M}$ concentrations compared to the group treated with 10 $\mu \mathrm{M}(\mathrm{p}=0.009, \mathrm{p}<0.001, \mathrm{p}<0.001)$ thymoquinone. When AKT gene expression levels were compared, a statistically significant reduction was found for $15 \mu \mathrm{M}$ thymoquinone treated cells compared to the control group $(\mathrm{p}=0.025)$.
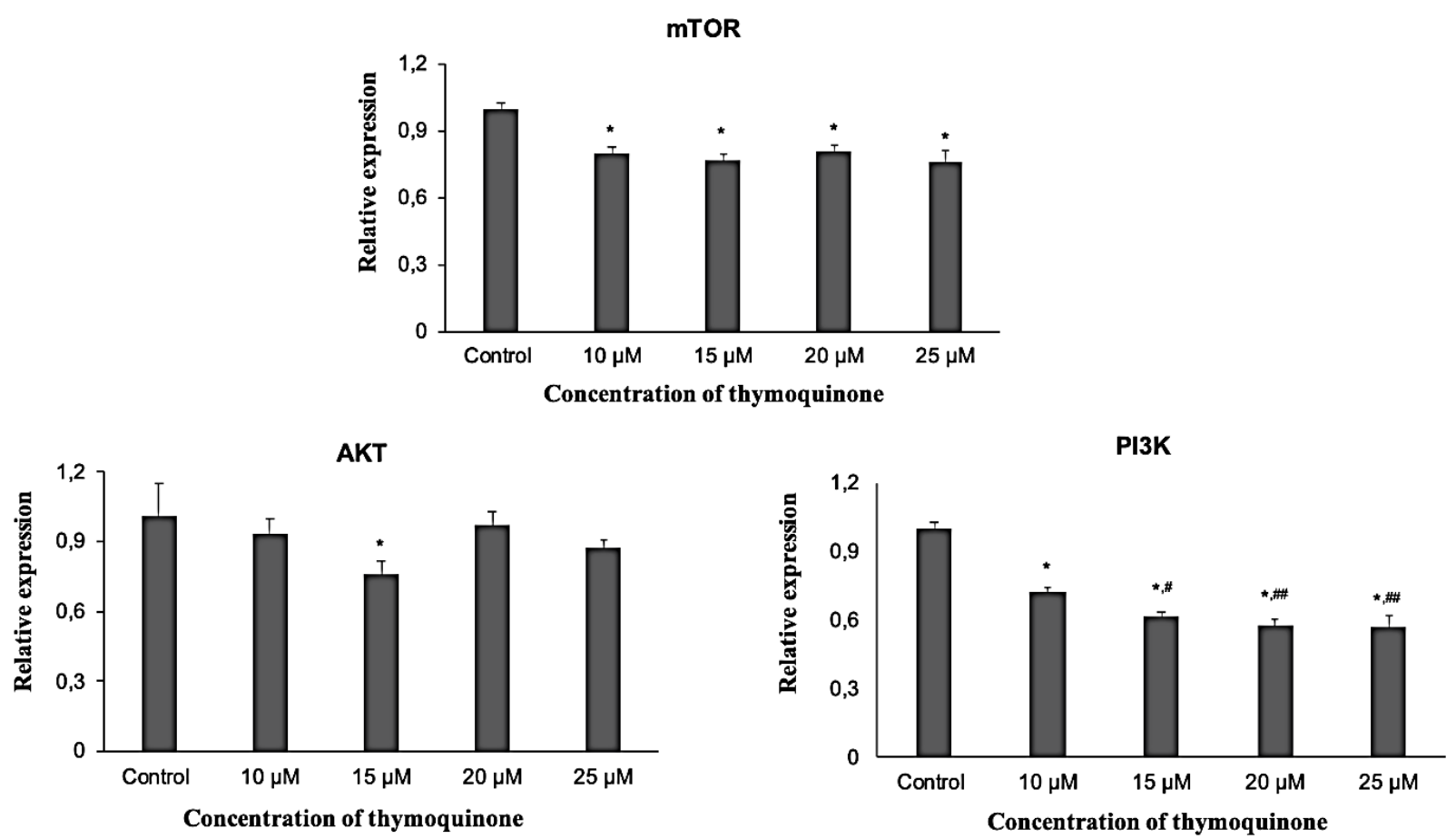

Fig. 4. The effects of thymoquinone on expression levels of mTOR, AKT, and PI3K genes in HL-60 cells. The values of each group are given as mean \pm standard deviation (SD). ${ }^{*} \mathrm{p}<0.001$ significant difference compared to the control, $* * \mathrm{p}<0.05$ significant difference compared to the control, ${ }^{\#} \mathrm{p}<0.01$ significant difference compared to $10 \mu \mathrm{M}$ treatment group, ${ }^{\# \#} \mathrm{p}<0.001$ significant difference compared to $10 \mu \mathrm{M}$ treatment group. 
A1

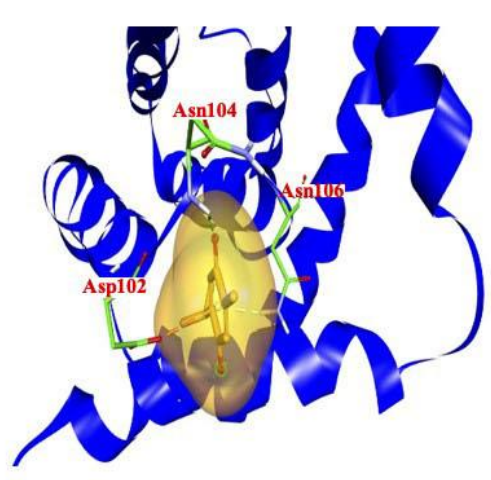

A2

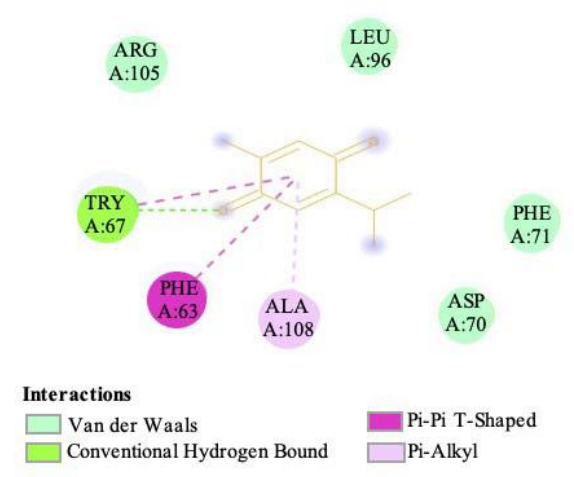

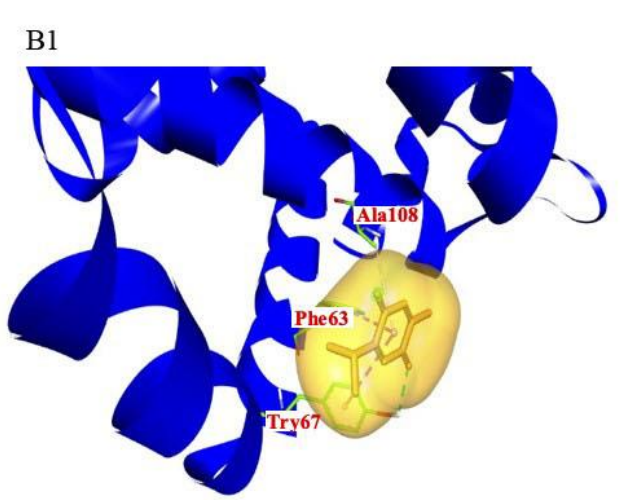

$\mathrm{C} 1$

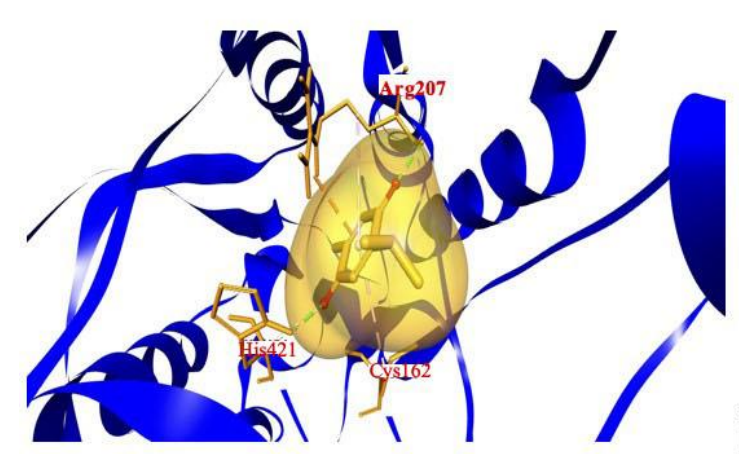

B2

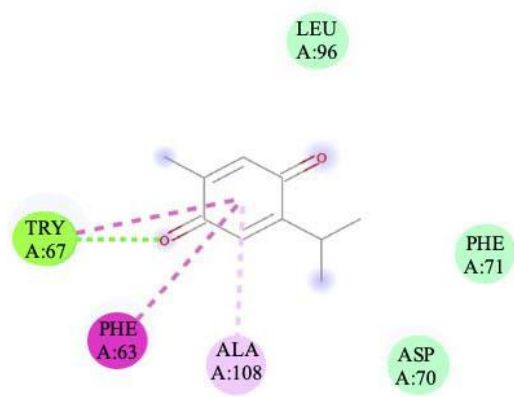

Interactions

Van der Waals

Conventional Hydrogen Bound
Pi-Pi T-Shaped Pi-Alkyl

C2

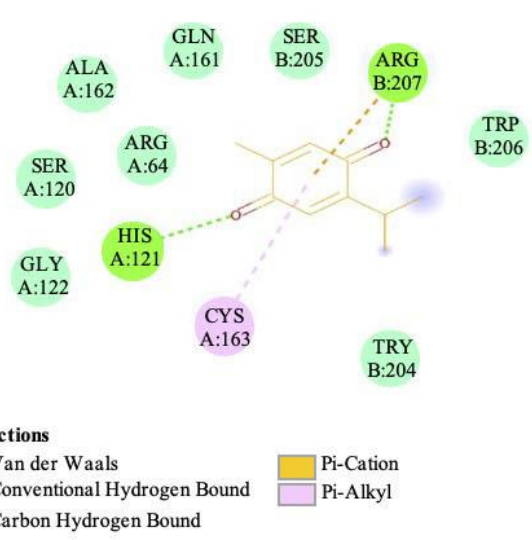

Fig. 5. Docking results of thymoquinone in the active sites of Bax, Bcl-2, and caspase 3, proteins. A1: Docking pose of thymoquinone in the active site of Bax; A2: Interactions of thymoquinone in the active site of Bax; B1: Docking pose of thymoquinone in the active site of Bcl-2; B2: Interactions of thymoquinone in the active site of Bcl-2; $\mathrm{C} 1$ : Docking pose of thymoquinone in the active site of caspase 3; C2: Interactions of thymoquinone in the active site of caspase 3.

\section{Molecular Docking Studies}

Molecular docking simulations were implemented to reveal the potential binding modes of thymoquinone to the active sites of Bax, Bcl-2, caspase 3, PI3K, AKT, and mTOR (March 25, 2021). The docking results of thymoquinone specified that hydrophobic interactions and $\mathrm{H}$ bonds were responsible for the detected affinity (Figs 5, 6). Bax, Bcl-2, caspase 3, PI3K, AKT, and mTOR docked with thymoquinone with scores $-4.3,-5.2,-$ $5.2,-6.5,-7.5$, and $-5.9 \mathrm{kcal} / \mathrm{mol}$, respectively (Table 3).
However, the table ensures information for interacting residues with respective atomic contacts. All proteins had high affinity and strongly bonded with polar contacts (Table 3). The polar and nonpolar amino acid residues interacted with thymoquinone. Table 3 shows that Bax contains ASN104, ASN106, and ASP102; Bcl-2 contains TYR67, PHE63, TYR67, and ALA108; caspase 3 contains HIS121, ARG207, HIS121, ARG207, CYS163, and ARG207; PI3K contains ASP964, ILE879, and ILE963; AKT contains ALA230, LEU15, and ALA77; mTOR contains VAL2240, MET2345, MET2345, TRP2239, and TRP2239. 

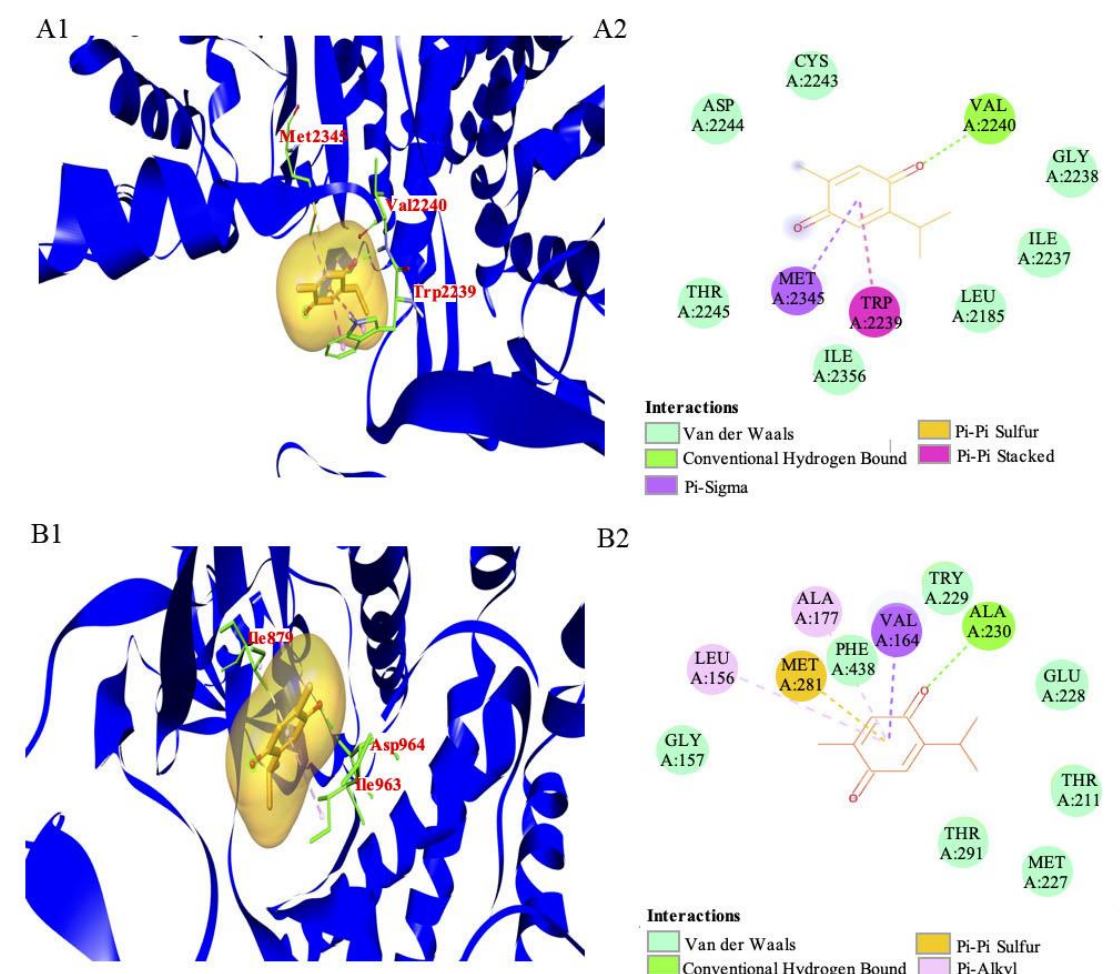

B2
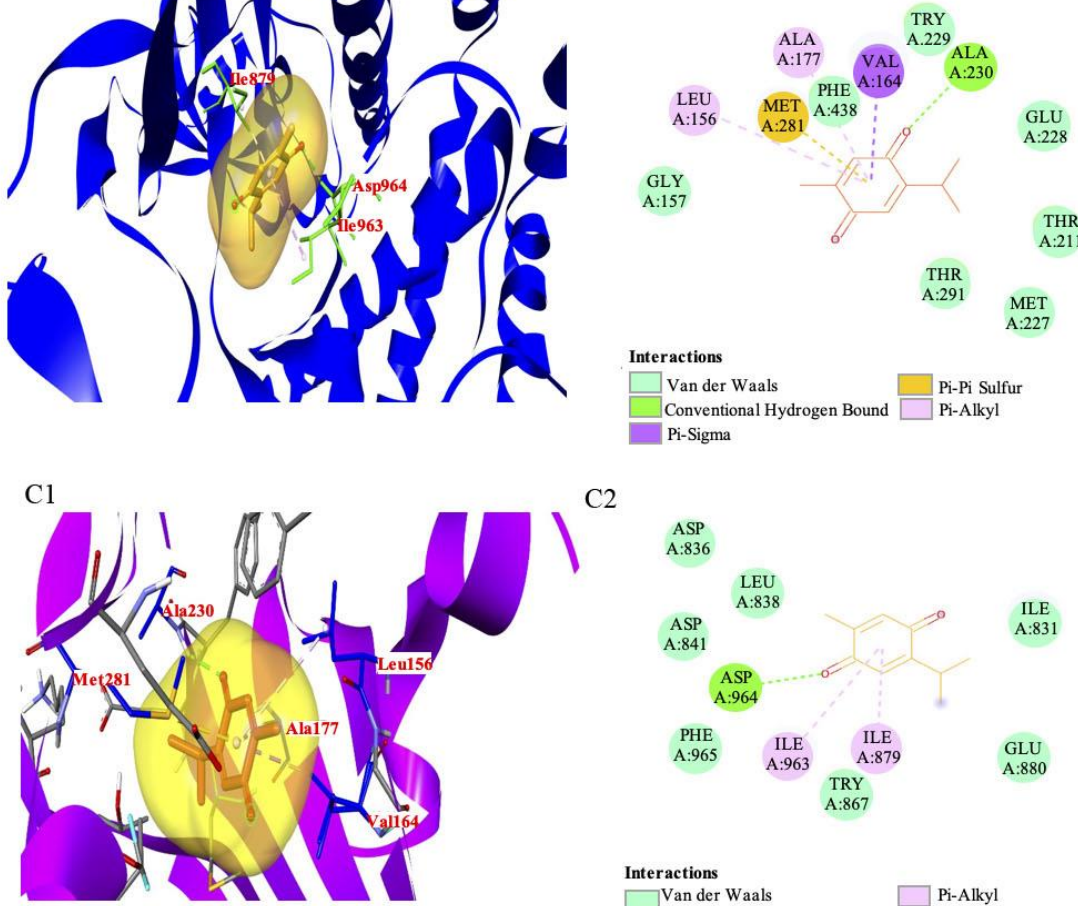

$\mathrm{C} 2$
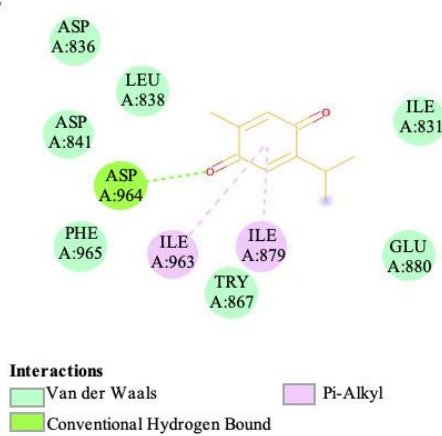

Fig. 6. Docking results of thymoquinone in the active site of mTOR, PI3K, and AKT proteins A1: Docking pose of thymoquinone in the active site of mTOR; A2: Interactions of thymoquinone in the active site of mTOR; B1: Docking pose of thymoquinone in the active site of PI3K; B2: Interactions of thymoquinone in the active site of PI3K; C1: Docking pose of thymoquinone in the active site of AKT; C2: Interactions of thymoquinone in the active site of AKT.

Table 3. Binding energy values and the important amino acids in the active sites of the Bax, Bcl-2, caspase 3, PI3K, AKT, and mTOR proteins which are responsible for interactions.

\begin{tabular}{cccccccc}
\hline \hline & & \multicolumn{5}{c}{ Parameters } \\
\cline { 3 - 8 } Receptors & $\begin{array}{c}\text { Compound } \\
\text { name }\end{array}$ & $\begin{array}{c}\text { Binding } \\
\text { energy } \\
(\mathrm{kcal} / \mathrm{mol})\end{array}$ & $\begin{array}{c}\text { Number of } \\
\text { hydrogen } \\
\text { bonds }\end{array}$ & $\begin{array}{c}\text { Hydrogen } \\
\text { Bonding with } \\
\text { Amino acid } \\
\text { residues }\end{array}$ & $\begin{array}{c}\text { Number of } \\
\text { hydrophobic } \\
\text { interactions }\end{array}$ & $\begin{array}{c}\text { Hydrophobic Bonding } \\
\text { with Amino acid residues }\end{array}$ & $\begin{array}{c}\text { Distance } \\
(\AA)\end{array}$ \\
\hline Bax & -4.3 & 2 & ASN104-ASN106 & 1 & ASP102 & 2.5802 \\
Bcl-2 & & -5.2 & 1 & TYR67 & 3 & PHE63-TYR67-ALA108 & 2.51399 \\
caspase 3 & Thymoquinone & -5.2 & 3 & HIS121-ARG207- & 3 & ARG207-CYS163-ARG207 & 2.08891 \\
PI3K & & -6.5 & 1 & ASP121 & 2 & ILE879-ILE963 & 2.12918 \\
AKT & & -7.5 & 1 & ALA230 & 4 & $\begin{array}{l}\text { VAL164-MET281-LEU15- } \\
\text { ALA177- }\end{array}$ \\
mTOR & & -5.9 & 1 & VAL2240 & 4 & $\begin{array}{l}\text { MET2345-MET2345- } \\
\text { TRP2239-TRP2239 }\end{array}$ & 2.23519 \\
\hline \hline
\end{tabular}




\section{Discussion}

Cancer is one of the world's greatest health problems, so the identification of new antitumor drugs is of paramount importance. Pharmaceutical plants are good sources of biologically active compounds that contain antioxidant and immunomodulatory features, making them potential candidates as anticancer agents (Majoloab et al. 2019). In addition to being edible (Samarghandian et al. 2019), natural compounds are also gaining attention as cancer therapeutic agents due to their more effective but less toxic profile (Gupta et al. 2013).

The precise mechanisms underlying thymoquinone's anticancer effects have not been fully discovered. There are not enough studies investigating the apoptotic and autophagic effects of thymoquinone in AML HL-60 cells. Therefore, apoptotic and autophagic mechanisms were evaluated by looking at the effect of thymoquinone on Bax, Bcl-2, caspase 3, mTOR, AKT and PI3K gene expressions in HL-60 cells in the present study.

Thymoquinone has a low overall toxicity as well as promising anti-tumor activity (Effenberger-Neidnicht \& Schobert 2011). Studies showed that thymoquinone can prevent the proliferation of human promyelocytic leukemia HL-60 cells through apoptotic cell death (Racoma et al. 2013). According to the results of MTT test, it was determined that thymoquinone prevents the proliferation rate of HL-60 cells in a dose-dependent way. Such an inhibitory effect may be related to the apoptotic properties of thymoquinone. After this finding, the focus was shifted to apoptotic and autophagic gene markers to explain the influence of thymoquinone on cell death mechanisms.

Apoptotic induction induced movement of Bax from cytosol to mitochondria, leading to multimerization, integration and cytochrome c release, caspase activation, and apoptotic cell death (Aykaç et al. 2015). While Bcl-2 defends cells from apoptotic cell death, the over expression of Bax can stimulate apoptosis (Salim et al. 2014). In the current study, a reduction in Bcl-2 gene expression levels was detected in cells treated with 10 $\mu \mathrm{M}, 15 \mu \mathrm{M}, 20 \mu \mathrm{M}$, and $25 \mu \mathrm{M}$ thymoquinone compared to the the control. A higher level of Bcl-2 gene expression was detected in cells applied with $15 \mu \mathrm{M}$ of thymoquinone compared to other treatment groups. This result suggests that the anticancer effects of thymoquinone may possibly be associated with the inhibition of antiapoptotic gene expression of Bcl-2. In HL-60 cell line, there was no alteration in Bax expression level in the groups applied with thymoquinone compared to the control. Bax/ $\mathrm{Bcl}-2$ ratio instead of $\mathrm{Bcl}-2$ alone is important for the occurrence of drug-induced apoptosis in leukemia cell lines (Salim et al. 2014). Bax/Bcl-2 ratio determines the sensitivity or resistance of cells to apoptotic inducements, containing cure with natural compounds (Christodoulou et al. 2014). Although Bax ratio did not change in the present study, it was found that $\mathrm{Bax} / \mathrm{Bcl}-2$ proportion was higher in the thymoquinone applied groups compared to the control. The rise in Bax/Bcl-2 proportion determined in the study was consistent with recent studies using MCF-7 (Woo et al. 2011), HL-60 (El-Mahdy et al. 2005) and HCT116 (GaliMuhtasib et al. 2004b) cancer cells. The increase in the proportion of total $\mathrm{Bax} / \mathrm{Bcl}-2$ proposes that it may be one of the thymoquinone induced apoptosis mechanisms.

Induction of apoptotic cell death is an important mechanism for cancer prevention (Zhang et al. 2012). Apoptogenic factors release and activate caspases, which are the promoters of apoptosis (Chen et al. 2017). Caspase 3 is the most significant mediator of apoptosis and is often used to determine apoptotic activity (Huang et al. 2010). Caspase 3 is the driving factor of apoptotic cell death, as it activates endonucleases to break down nuclear DNA, resulting in DNA fragmentation leading to cell death (Chen et al. 2017). Resistance to apoptotic stimuli, including chemotherapeutic agents, in leukemia is known to be due to insufficient expression of caspase 3 (Fricdrich et al. 2001). In many reports using thymoquinone, the role of the caspase pathway in apoptosis has been determined (Paramasivam et al. 2012). El-Mahdy et al. (2005) stated that thymoquinone stimulated apoptotic cell death in HL60 cells was due to caspase activation. In the present study, a reduction in caspase 3 expression levels was determined in HL-60 cell line in the groups treated with $10 \mu \mathrm{M}, 15 \mu \mathrm{M}$, and $25 \mu \mathrm{M}$ thymoquinone compared to the control. The decrease in caspase 3 expression level was an unexpected finding. However, the decrease in caspase 3 level with selected doses of thymoquinone therapy proposes that cancer cells downregulate caspase 3 expression to escape apoptosis. It means that downregulation of caspases may indicate a resistance mechanism of cancer cells to thymoquinone stimulated apoptosis. However, this result suggests that thymoquinone induced cell death may be due to the activation of a different pathway that occurs independently of caspase 3 . Therefore, genes in the autophagic pathway were further analyzed in the present study.

The role of autophagy in tumors continuously alters with the development of the tumors. Autophagy suppresses the onset of cancer by removing genome imbalance, inflammation, and tissue injury in the early stages of tumor formation. mTOR is a serine / threonine protein kinase that regulates autophagic progression (Meng et al. 2020). It has been reported that mTOR is a negative regulator of autophagy, and mTOR inhibition can trigger autophagy (Fan et al. 2018). mTOR is regulated by a kinase cascade that includes class I phosphatidylinositol 3-kinase (PI3K) and serine / threonine kinase (AKT). PI3K activates AKT, which then activates mTOR (Meng et al. 2020). Studies showed that autophagy can be mediated in a variety of ways, containing PI3K/AKT/mTOR (Zhang et al. 2018b). $\mathrm{PI} 3 \mathrm{~K} / \mathrm{AKT} / \mathrm{mTOR}$ pathway modulates various cellular events that are also important for carcinogenesis, such as cell metabolism, cell cycle progression, cell proliferation, 
angiogenesis, autophagy and apoptosis. Recently, intensive endeavors have been taken on inhibitors of $\mathrm{PI} 3 \mathrm{~K} / \mathrm{AKT} / \mathrm{mTOR}$ pathway to cure cancers and discover new inhibitors, due to the significantly altered expression of PI3K/AKT/mTOR proteins in various tumors (Pathania et al. 2013). This pathway can be manipulated to induce autophagy in cancer cells as cancer cells continuously initiate $\mathrm{PI} 3 \mathrm{~K} / \mathrm{AKT} / \mathrm{mTOR}$, which negatively regulates autophagy (Kuttikrishnan et al. 2019). Upregulation of mTOR pathway has been stated in many oncogenic disorders, including acute and chronic leukemias. mTOR activation is usually induced by PI3K/AKT (Paramasivam et al. 2019). While studies showed that thymoquinone can stimulate autophagy in drug-resistant colon cancer cells and squamous carcinoma cells (Zhang et al. 2018b), the influence of thymoquinone on autophagy in HL60 cell lines has not been studied. However, in studies of Iskender et al. (2016a, b) on bladder cancer, thymoquinone was reported to weaken mTOR activity and inhibit PI3K/AKT signal. In the present study, it was determined that four different thymoquinone concentrations $(10 \mu \mathrm{M}, 15 \mu \mathrm{M}$, $20 \mu \mathrm{M}$, and $25 \mathrm{mM}$ ) decreased mTOR and PI3K gene expressions compared to the control group. Several other studies have suggested that thymoquinone may exert its inhibitory effects on cell proliferation through regulating the activity of AKT, a known positive modulator of cell survival (Majdalawieh et al. 2017). It was determined that AKT gene expression level decreased in the group treated with $15 \mu \mathrm{M}$ of thymoquinone compared to the control. AKT inhibition may be responsible for the decrease in mTOR activity.

Today, the use of in silico methods help scientists in the discovery of medical agents and play a very important role in structure-based drug design. As cancer cells are more prone to apoptosis, a comprehensive understanding of the molecular pathways that regulate apoptosis may aid in the search for new cancer chemotherapeutic targets. This will open up new opportunities for drug discovery and development (Sitheek et al. 2020). The docking explorations in the present study were done with the purpose of defining possible anticancer action mechanisms of thymoquinone. The binding energy, hydrogen bond interaction and hydrophobic interaction

\section{References}

1. Ahmad, A., Husain, A., Mujeeb, M., Khan, S.A., Najmi, A.K., Siddique, N.A., Damanhouri, Z.A. \& Anwar, F. 2013. A review on therapeutic potential of Nigella sativa: A miracle herb. Asian Pacific Journal of Tropical Biomedicine, 3: 337-352.

2. Al-Otaibi, N.A.S., Cassoli, J.S., Slater, N.K.H. \& Rahmounc, H. 2019. Molecular characterization of human leukemia 60 (HL-60) cells as a model of acute myelogenous leukemia post cryopreservation. Methods in Molecular Biology, 1916: 239-247.

3. Artun, F.T. \& Karagöz, A. 2021. Antiproliferative and apoptosis inducing effect of the methanolic extract of Centaurca hermannii in human cervical cancer cell line. Biotechnic and Histochemistry, 96:1-10. between the thymoquinone and apoptotic and autophagic proteins were documented for further consideration. The results showed that there is a presence of binding site between Bax, Bcl-2, caspase 3, mTOR, PI3K, and AKT proteins and thymoquinone. The docking study is valid especially for the formation of hydrogen bond among thymoquinone and PI3K, AKT, and mTOR. Thymoquinone showed $\mathrm{H}$-bond interactions with residues that were advised to be necessary for inhibitory activity. The interactions showed optimal binding features for further consideration of thymoquinone as a possible drug candidate in cancer exploration. Therefore, $\mathrm{PI} 3 \mathrm{~K} / \mathrm{AKT} / \mathrm{mTOR}$ pathway can be an encouraging goal for anticancer drug design.

In the present study, it was determined that thymoquinone application affects the expression levels of mTOR, AKT, and PI3K genes that promote cell viability, proliferation and progression in cancer cells. PI3K, AKT, and mTOR gene expressions were down-regulated in response to treatment with thymoquinone. This study is the first to emphasize that thymoquinone can significantly prevent the proliferation of HL-60 cells by preventing the PI3K/AKT/mTOR pathway and inducing apoptosis. These observations suggest that it may lead to the development of new therapeutic approaches for human cancers targeting PI3K/AKT/mTOR signaling pathway. These data demonstrate the new and imperative function of thymoquinone in PI3K/AKT/mTOR signaling pathway in the cell death mechanism of HL-60 cell lines.

\section{Acknowledgement}

I would like to thank Biotechnologist Mehmet KARATAŞ for his kind help in the determination of molecular docking study.

Ethics Committee Approval: Since the article does not contain any studies with human or animal subject, its approval to the ethics committee was not required.

Conflict of Interest: The author have no conflicts of interest to declare.

Funding: The study was supported by the Aksaray University Scientific Research Fund with project number 2017-058.

4. Aykaç, A., Gören, M.Z. \& Cabadak, H. 2015. Altered ratio of proapoptotic and antiapoptotic proteins in different brain regions of female rats in model of post-traumatic stress disorder. Turkish Journal of Biochemistry, 40: 1-7.

5. Banerjee, S., Kascb, A.O., Wang, Z., Kong, D., Mohammed, M., Padhye, S., Sarkar, F.H. \& Mohammed, R.M. 2009. Antitumor activity of gemcitabine and oxaliplatin is augmented by thymoquinone in pancreatic cancer. Cancer Research, 69: 5575-5583.

6. Bashmail, H.A., Alamoudi, A.A., Noorwali, A., Hegazy, G.A., AJabnoor, G.M. \& Al-Abd, A.M. 2020. Thymoquinone enhances paclitaxel anti-breast cancer activity via inhibiting tumor-associated stem cells despite apparent mathematical antagonism. Molecules, 25: 426. 
7. Bashmail, H.A., Alamoudi, A.A., Noorwali, A., Hegazy, G.A., AJabnoor, G.M., Choundhry, H. \& Al-Abd, A.M. 2018. Thymoquinone synergizes gemcitabine anti-breast cancer activity via modulating its apoptotic and autophagic activities. Scientific Reports, 8: 11674.

8. Chang, C.H., Lee, C.H., Lu, C.C., Tsai, F.J., Hsu, Y.M., Tsao, J., Juan, Y.N., Chiu, H.Y., Yang, J.S. \& Wang, C.C. 2017. Resveratrol-induced autophagy and apoptosis in cisplatin-resistant human oral cancer CAR cell: A key role of AMPK and AKT $/ \mathrm{mTOR}$ signaling. International Journal of Oncology, 50: 873-882.

9. Chen, A., Wang, H., Zhang, Y., Wang, X., Yu, L., Xu, W., Xu, W. \& Lin, Y. 2017. Paeoniflorin exerts neuroprotective effects against glutamate-induced PC12 cellular cytotoxicity by inhibiting apoptosis. International Journal of Molecular Medicine, 40: 825-883.

10. Christodoulou, M.I., Kontos, C.K., Halabalaki, M., Skaltsounis, A.L. \& Scorilas, A. 2014. Nature promises new anticancer agents: Interplay with the apoptosis-related BCL2 gene family. Anti-Cancer Agents in Medicinal Chemistry, 14: 375-399.

11. Effenberger-Neidnicht, K. \& Schobert, R. 2011. Combinatorial effects of thymoquinone on the anti-cancer activity of doxorubicin. Cancer Chemotherapy and Pharmacology, 67: 867-874.

12. El-Mahdy, M.A., Zhu, Q., Wang, Q., Wani, G. \& Wani, A.A. 2005. Thymoquinone induces apoptosis through activation of caspase- 8 and mithocondrial events in p53null myloblastic leukemia HL-60 cells. International Journal of Cancer, 117: 409-417.

13. Fan, Y., Chiu, J.F., Liu, J., Deng, Y., Xu, C., Zhang, J. \& Li, G. 2018. Resveratrol induces autophagy-dependent apoptosis in HL-60 cells. BioMed Central Cancer Cancer, 18: 582 .

14. Fricdrich, K., Wicder, T., Haefen, C.V., Radetzki, S., Janicke, R., Schulze-Osthoff, K., Dörken, B. \& Danie, P.T. 2001. Overexpression of caspase-3 restores sensitivity for drug-induced apoptosis in breast cancer cell lines with acquired drug resistance. Oncogene, 20: 2749-2760.

15. Gali-Muhtasib, H., Diab-Assaf, M., Boltze, C., Al-Hmaira, J., Harting, R., Roessner, A. \& Schneider-Stock, R. 2004a. Tyhmoquinone extracted from black seed triggers apoptotic cell death in human colorectal cancer cell via a p53-dependent mechanism. International Journal of Oncology, 25: 857-866.

16. Gali-Muhtasib, H.U., Abou-Kehr W.G., Kehr, L.A., Darreiche, N. \& Crooks, P.A. 2004b. Molecular pathway for thymoquinone-induced cell-cycle arrest and apoptosis in neoplastic keratinocytes. Anti-Cancer Drugs, 15: 38999.

17. Ge, J., Liu, Y., Li, Q., Guo, X., Gu, L., Ma, Z.G. \& Zhu, Y.P. 2013. Resveratrol induces apoptosis and autophagy in $\mathrm{T}$ cell acute lymphoblastic leukemia cells by inhibiting Akt/mTOR and acting p38 MAPK. Biomedical and Environmental Sciences, 26: 902-911.

18. Gupta, R.K., Banerjee, A., Pathak, S., Sharma, C. \& Singh, N. 2013. Induction of mithocondrial-mediated apoptosis by Morinda citrifolia (Noni) in human cervical cancer cells. Asian Pacific Journal of Cancer Prevention, 14: 237-242.
19. Gurung, R.L., Lim, S.N., Khaw, A.K., Soon, J.F., Shenoy, K., Mohammed-Ali, S., Jayapal, M., Sethu, S., Baskar, R. \& Hande, M. 2010. Tyhmoquinone induces telomere shortening, DNA damage and apoptosis in human glioblastoma cells. Plos One, 5: e12124.

20. Huang, H., Zhang, X.F., Zhou, H.J., Xue, Y.H., Dong, Q.Z., Yc, Q.H. \& Qin, L.X. 2010. Expression and prognostic significance of osteopontin and caspase-3 in hepatocellular carcinoma patients after curative resection. Cancer Science, 101: 1314-1319.

21. Iskender, B., Izgi, K. \& Canatan, H. 2016a. Novel anticancer agent myrtucommulonc-A and thymoquinone abrogate epithelialmesenchymal transition in cancer cells mainly through the inhibition of PI3K/AKT signaling axis. Molecular and Cellular Biochemistry, 416: 71-84.

22. Iskender, B., Izgi, K., Hizar, E., Arslanhan, A., Yüksek, E.H. \& Canatan, H. 2016b. Inhibition of epithelialmesenchymal transition in bladder cancer cells via modulation of mTOR signalling. Tumor Biology, 37: 82818291.

23. Kahl, M., Brioli, A., Bens, M., Perner, F., Kreisky, A., Schnetzle, U., Hinze, A., Sbirkov, Y., Stengel, S., Simonetti, G., Petrie, K., Zelent, A., Böhmer, F.D., Groth, M., Ernst, T., Heidel, F.H., Scholl, S., Hochhaus, A. \& Schenk, T. 2019. The acetyltransferase GCN5 maintains ATRA-resistance in non-APL AML. Leukemia, 33: 26282639.

24. Krumar, D., Das, B., Sen, R., Kundu, P., Manna, A., Sarkar, A., Chowdhury, C., Chatterje, M. \& Das, P. 2015. Andrographolide analoge induces apoptosis and autophagy mediated cell death in U937 cells by inhibition of PI3K/Akt/mTOR pathway. Plos One, 10: e0139657.

25. Kuttikrishnan, S., Siveen, K.S., Prabhu, K.S., Khan, A.Q., Ahmed, E.I., Akhtar, S., Ali, T.A., Merhi, M., Dermime, S., Steinhoff, M. \& Uddin, S. 2019. Curcumin Induces Apoptotic Cell Death via Inhibition of PI3-Kinase/AKT Pathway in B-Precursor Acute Lymphoblastic Leukemia. Frontiers in Oncology, 9: 484.

26. Liu, F., Gao, S., Yang, Y., Zhao, X., Fan, Y., Ma, W., Yang, D., Yang, A. \& Yu, Y. 2018. Antitumor activity of curcumin by modulation of apoptosis and autophagy in human lung cancer A549 cells through inhibiting PI3K/Akt/mTOR pathway. Oncology Reports, 39: 15231531.

27. Maha, A., Cheong, S.K., Leong, C.F. \& Show H.F. 2008. Cell viability of acute myeloid leukaemia blast in culture correlates with treatment outcome. Hematology, 13: 13-20.

28. Majdalawieh, A.F., Fayyad, M.W. \& Nasrallah, G.K. 2017. Anti-cancer properties and mechanism of action of thymoquinone, the major active ingredient of Nigella sativa. Critical Reviews in Food Science and Nutrition, 57: 3911-3928.

29. Majoloab, F., Knabbende, L., Delwinga, L.K.O.B., Marnitta, D.J., Bustamente-Filhoc, I.C. \& Goettert, M.I. 2019. Medicinal plants and bioactive natural compounds for cancer treatment: Important advances for drug discovery. Phytochemistry Letters, 31: 196-207.

30. Meng, X, Xia, C., Ye, Q. \& Nie, X. 2020. Tert-Butyl-pbenzoquinone induces autophagy by inhibiting the 
Akt/mTOR signaling pathway in RAW 264.7 cells. Food and Function, 1: 4193-4201.

31. Morris, G.M., Huey, R., Lindstrom, W., Sanner, M.F., Belew, R.K., Goodsell, D.S. \& Olson, A.J. 2009. AutoDock4 and AutoDockTools4: automated docking with selective receptor flexibility. Journal of Computational Chemistry, 30: 2785-27891.

32. Mosmann, T. 1983. Rapid colorimetric assay for cellular growth and survival: application to proliferation and cytotoxicity assays. Journal of Immunological Methods, 65: 55-63.

33. Ng, W.K., Yazan, L.S. \& İsmail, M. 2011. Thymoquinone from Nigella sativa was more potent than cisplatin in eliminating of $\mathrm{SiHa}$ cell via apoptosis with downregulation of Bcl-2 protein. Toxicology in Vitro, 25: 13921398.

34. Paramasivam, A., Sambantham, S., Shabnam, J., Raghunandhakumar, S., Anandan, B., Rajiv, R., Priyadharsini, J.V. \& Jayaraman, G. 2012. Anti-cancer effect of thymoquinone in mouse neuroblastoma (Neuro2a) cells through caspase-3 activation with downregulation of XIAP. Toxicology Letters, 213: 151-159.

35. Pathania, A.S., Guru, S.K., Verma, M.K., Sharma, C., Abdullah, S.T., Malik, F., Chandra, S., Katoch, M. \& Bhushan, S. 2013. Disruption of the PI3K/AKT/mTOR signaling cascade and induction of apoptosis in HL-60 cells by an essential oil from Manarda citriodora. Food and Chemical Toxicology, 62: 246-254.

36. Peng, L., Liu, A., Shen, Y., Xu, H.Z., Yang, S.Z., Ying, X.Z., Liao, W., Liu, H.X. \& Lin, Z.Q. Chen, Q.Y., Cheng, S.W. \& Shen, W.D. 2013. Antitumor and anti-angiogenesis effects of thymoquinone on osteosarcoma through the NFкB pathway. Oncology Reports, 29: 571-578.

37. Racoma, I.O., Meisen, W.H., Wang, Q.E., Kaur, B. \& Wani, A.A. 2013. Thymoquinone inhibits autophang and induces cathepsin-mediated, caspase-independent cell death in glioblastoma cells. Plos One, 8: e72882.

38. Saiki, S., Sasazawa, Y., Imamichi, Y., Kawajiri, S., Fujimaki, T., Tanida, I., Kobayashi, H., Sato, F., Sato, S., Ishikawa, K., Imoto, M. \& Hattori, N. 2011. Caffeine induces apoptosis by enhancement of autophagy via PI3K/Akt/mTOR/p70S6K inhibition. Autophagy, 7: 176187.

39. Salim, L..ZA., Othman, R., Abdulla, M.A., Al-Jashamy, K., Ali, H.M., Hassandarvish, P., Dehghan, F., Ibrahim,
M.Y., Omer, F.A. \& Mohan, S. 2014. Thymoquinone inhibits murine leukemia WEHI-3 cells in vivo and in vitro. Plos One, 9: e115340.

40. Samarghandian, S., Nezhad-Azimi, M. \& Farkhondeh, T. 2019. Thymoquinone-induced antitumor and apoptosis in human lung adenocarcinoma cells. Journal of Cellular Physiology, 234: 10421-10431.

41. Sitheek, M.A., Sivakumari, K., Rajesh, S. \& Ashok, K. 2020. Molecular docking studies of apoptotic proteins Caspase-3, Caspase-9, Bax, Bcl-2 and Bcl-Xl with Ethyl (2s)-2-methyl butanoate and 1-(ethylsulfanyl) ethane-1thiol from durian fruit. International Journal of Biology, Pharmacy and Applied Sciences, 9: 2513-2523.

42. Sun, J., Feng, Y., Wang, Y., Ji, Q., Cai, G., Shi, L., Wang, Y., Huang, Y., Zhang, J. \& Li, Q. 2019. a-hederin induces autophagic cell death in colorectal cancer cells through reactive oxygen species dependent AMPK/mTOR signaling pathway activation. International Journal of Oncology, 54: 1601-1612.

43. Woo, C.C., Loo, S.Y., Gee, V., Yap, C.W., Sethi, G., Kumar, A.P. \& Tan, K.H. 2011 Anticancer activity of thymoquinone in breast cancer cells: possible involvement of PPAR gamma pathway. Biochemical Pharmacology, 82: 464-475.

44. Zhang, C.L., Zeng, T., Zhao, X.L., Yu, L.H., Zhu, Z.P. \& Xie, K.Q. 2012. Protective effects of garlic oil on hepatocarcinoma induced by n-nitrosodieethylamine in rats. International Journal of Biological Sciences, 8: 363374 .

45. Zhang, M., Du, H., Huang, Z., Zhang, P., Yue, Y., Wang, W., Liu, W., Zeng, J., Ma, J., Chen, G., Wang, X. \& Fan, J. 2018a. Thymoquinone induces apoptosis in bladder cancer cell via endoplasmic reticulum stress-dependent mitochondrial pathway. Chemico-Biological Interactions, 292: 65-75.

46. Zhang, Y., Fan, Y., Huang, S., Wang, G., Han, R., Lei, F., Luo, A., Jing, X., Zhao, L., Gu, S. \& Zhao, X. 2018 b. Thymoquinone inhibits the metastasis of renal cell cancer cell by inducing auto-handy via AMPK/mTOR signaling pathway. Cancer Science, 109: 3865-3873.

47. Zhou, Z.W., Li, X.X., He, Z.X., Pan, S.T., Yang, Y., Zhang, X., Chow, K., Yang, T., Qui, J.X., Zhou, Q., Tan, J., Wang, D. \& Zhou, S.F. 2015. Induction of apoptosis and autophagy via sirtuin 1 and PI3K/Akt/mTOR mediated pathways by plumbagin in human prostate cancer cells. Drug Design, Development and Therapy, 9: 1511-54. 